\title{
Study on Logistics Barriers to Procurement from the Chinese Market
}

\author{
Lan-Feng $\mathrm{YU}^{1, \mathrm{a},{ }^{*}}$ \\ ${ }^{1}$ Faculty of International Communication Gunma Prefectural Women's University Gunma, 370-1193, \\ Japan \\ ayu@gpwu.ac.jp \\ ${ }^{*}$ Corresponding author
}

Keywords: Logistics Barriers, Overseas Procurement, Chinese Market.

\begin{abstract}
Logistics barriers are rapidly becoming critical issues of international operations and global procurement. To better understand logistics problems in an international production base and in a potentially huge market such as China, we employ empirical analysis and qualitative data collected via interview in this study. The findings show that quality, cost, and delayed delivery are the critical challenges in procurement from China. In fact, they are seriously affected by logistics problems. Also, the logistics flow within China is where most problems regarding logistics arise in the entire business operation. The study also reveals that a rise in logistics costs, local labor costs, and a shortage of human resources are becoming new concerns in procurement from the Chinese Market.
\end{abstract}

\section{Introduction}

An increasing number of foreign firms are entering China to take advantage of the business opportunities in the potentially huge market since China joined the WTO in 2000. Japan is a leading country in investments in China, and the Foreign Direct Investment (FDI) from Japan has increased from 137.7 billion Yen in 1998 to 1,075.9 billion Yen in 2012 (MOF, 2013). Additionally, Japanese firms tried to establish local suppliers instead of importing from home. Recent data shows that local supply has increased to 50 percent from 10 percent in 1995 (JCIPO, 2007). Subsequently, there has been a rise in the distribution of materials and products in local markets. However, most of these firms encountered logistics barriers in distributing their products in China. The reason for this is the development of the Chinese logistics industry has fallen behind the rapid economic growth and increased demand for distribution.

The Chinese government has begun to formulate logistics as a strategic industry and invested heavily in improving infrastructure, such as nationwide multi-modal transportation networks and large-scale logistics centers. The logistics barriers foreign firms encountered in China have been changing, and some new challenges have become concerns for foreign firms.

This study aims to capture the specific logistics barriers and new challenges facing Japanese firms operating in China. The analysis is based on a reaserch of a Japanese retailer that manufactures its own brand products in China and sells in their stores in Japanese. Through research in this case study it has been identified that logistics greatly affected the business operation and performance in a huge developing market such as China. Foreign firms in different industries are establishing effective logistics functionality in China, and this is becoming an important strategy to support their entire business operations.

\section{Literature Review}

Many researchers have studied logistics problems facing foreign firms in China from various aspects. However, so far only a few have used case study to examine how Japanese manufacturing and distribution sectors deal with the management of logistics in China. Carter et al. (1997) conducted a survey to identify the logistics barriers that U.S. firms encountered in China. They found that logistics barriers were present in all aspects including purchasing, transportation, order processing, warehousing, inventory control, and import/export services. Ta et al. (2000) surveyed Singapore-based manufacturing firms in China and found that particular transportation problems 
were more serious than others. Easton (2003) indicated that China's supply chains were costly, inefficient and unreliable. In addition, the infrastructure and operational paradigms restrained economic development and limited the performance of local and foreign companies. Zhang \& Goffin (1999) identified four major problem areas: 1) recruiting and training employees, 2) supplier delivery, 3) quality output, and 4) achieving an effective business culture environment.

Fredriksson et al. (2009) developed a framework for low-cost sourcing assessment and exploring the consequences of low-cost sourcing in China for a European manufacturer. They pointed out that managers should be aware of how suppliers in low-cost countries may affect the structures, relations, and operational supply chain performances of the supply network. Lau and Zhang (2006) indicated that companies in China have encountered obstacles and problems in the outsourcing process. They include the lack of capable service providers, loss of control, poor transportation and IT infrastructure, presence of local protection regulations, and lack of overall post-outsourcing measurement. JCIPO (2003, 2005, and 2007) investigated the problems that Japanese firms encountered in their China's operations during the past few years. They summarized the four major problems areas: 1) human resources and labor management, 2) the relationship with Chinese government, 3) law and policies, 4) procurement of materials within China. The results show that most of the firms have suffered from quality, cost and delivery problems in their procurement in China.

Zhang and Goffin (2001) provided a case study on supplier management of joint ventures in China, and indicated that one difficulty facing JVEs was trying to simultaneously maintain quality levels while reducing costs by purchasing materials locally. Hayashi et al., (2010) provided a case study on Japanese auto manufacturers located in inland of China to procure auto parts under poor logistics infrastructure. They indicated that the distribution centers are excessive, the transportation routes are too complicated, and the logistics providers are unorganized and inconsistent especially in the cost management in China. They concluded that it is an important issue for auto manufactures to construct auto parts procurement networks and logistics systems to cope with severe conditions of inland China.

\section{Research Approach}

In prior research, $\mathrm{Yu}$ (2006) provided an overview of the current state and framework that hinder foreign firms' involvement to supply chain management in China. It highlighted the major issues that foreign firms face in their Chinese operations, such as fragmentation of logistics industry, supplier management, and third party logistics. It pointed out that the challenge to meet the business practice worldwide for Chinese logistics sectors is to learn and achieve supply chain efficiency and to modernize the logistics industry.

To further identify the specific logistics issues presently facing Japanese firms in their Chinese operations, a qualitative case study approach was deemed appropriate because it enables in-depth investigation and analysis of the case. Furthermore, this case study can examine current logistic practices. Case studies are a commonly adopted strategy in the area of logistics research (Bolumole, 2001; Hayashi et al., 2010; Zhang, 2001; Gunasekaran et al. 2004). In order to make the finding representative, a leading Home Center company, which manufactures its own brand products in China and sells in their stores in Japanese, was selected for this study.

The company has over 160 stores in 22 prefectures in Japan and is one of the top sales companies in the Japanese home center industry. While the industry as a whole is suffering from slow growth, the company maintains stronger sales by concentrating on the development of its own brand products, which enable them to provide high quality products at a low price. They currently offer about 12,000 items of own brand products and their sales account for over $30 \%$ of the turnover.

The reason for selecting this company is that its own brand products are manufactured in China and transported to stores in Japan. This case facilitates understanding of how manufacturing and distribution sectors deal with the management of logistics in China, and enables us to examine the problems facing shippers from the aspect of logistics. Additionally, an open-ended questionnaire was completed by the head of the procurement department in the company as a means to expand the depth of data gathering during the interview. The questionnaire focuses on the problems and barriers for 
doing business in China from the aspect of logistics. One section also required the respondent to identify the degree in which various barriers cause problems.

\section{Findings and Discussions}

\section{The logistics flow within China is where most problems regarding logistics arise in the entire business operation.}

As all the products are export-oriented, the products are first sent to one of the distribution center of the company, then to the nearest harbors, and finally exported to Japan. The logistics flow and problems in procurement from China are summarized in Table1.

Table1 The logistics flow and problems in procurement of the company

\begin{tabular}{|c|c|c|}
\hline The logistics flow & Logistics service providers & Current issues \\
\hline $\begin{array}{l}\text { (1) Factories } \\
\rightarrow \text { Company's } \\
\text { Distribution centers } \\
\text { (in China) }\end{array}$ & $\begin{array}{l}\text { - Chinese logistics providers } \\
\text { (Factories are responsible } \\
\text { for arranging and paying } \\
\text { for transportation) }\end{array}$ & $\begin{array}{l}\text { - Lack of container trucks } \\
\text { - Product breakages from } \\
\text { overloading } \\
\text { - Rough treatment of } \\
\text { shipments }\end{array}$ \\
\hline $\begin{array}{l}\text { (2) Company's } \\
\text { distribution centers } \\
\rightarrow \text { Harbors (in China) }\end{array}$ & - Japanese logistics providers & $\begin{array}{l}\text { Delayed deliveries caused } \\
\text { by troubles in customs } \\
\text { clearance }\end{array}$ \\
\hline $\begin{array}{l}\text { (3) Harbors (in China) } \\
\rightarrow \text { Harbors (in Japan) }\end{array}$ & $\begin{array}{l}\text { - Japanese customs agents } \\
\text { - Customs Clearance by } \\
\text { company }\end{array}$ & - Delayed port entry \\
\hline $\begin{array}{l}\text { (4) Harbors (in Japan) } \\
\rightarrow \text { Company's } \\
\text { distribution centers } \\
\text { (in Japan) }\end{array}$ & - Japanese customs agents & $\begin{array}{l}\text { - Congestion of container } \\
\text { yard. }\end{array}$ \\
\hline $\begin{array}{l}\text { (5) Company's } \\
\text { distribution centers } \\
\rightarrow \text { Stores (in Japan) }\end{array}$ & $\begin{array}{l}\text { - Affiliated Japanese } \\
\text { company }\end{array}$ & $\begin{array}{l}\text { - Loading capacity tends to be } \\
\text { low due to product category } \\
\text { delivery }\end{array}$ \\
\hline
\end{tabular}

Author summarized from the interviews.

Under the present system, various problems occur in the course of producing and transporting products, particularly concerning the logistics operation within China where most problems regarding logistics arise. As shown in Table 1, logistics service is outsourced to Chinese local providers only in the first step of the logistics flow: from factories to the company's warehouses. This is where most logistics problems occur. Some of the problems are caused by the lack of container trucks, product breakages from overloading, and rough treatment of shipments. In the Chinese market, firms utilizing offshore sourcing strategy have a high level of ownership control, but the management control tends to be low (Hong et al., 2006).

Quality, cost, and delayed delivery are the critical challenges in procurement from China. In fact, they are seriously affected by logistics problems.

The findings elicited from the case study indicate that the common problems in procurement facing Japanese firms can be grouped into three categories: quality, cost, and delayed delivery. The top three factors regarding difficulties and obstacles in procurement from China are summarized in Table 2. Quality and cost are very common issues for foreign firms sourcing or manufacturing in the Chinese market. On the other hand, we found that even logistics problems seriously affect quality, cost, and delivery. For instance, the quality of products deteriorates owing to the inadequacy of transport vehicles, materials storage, and management systems. Also, increased product cost is primarily 
derived from a rise in logistics cost. The delivery date is often not met for a number of reasons, such as the lack of container trucks (which causes water damage to shipment when it rains), rough handling of freight, and defective containers. Traffic restrictions that ban heavy vehicles from entering major cities also affect due dates. Transshipment caused by restrictions increases the logistics cost.

Additionally, these findings support the outcomes of the surveys conducted by JCIPO (2003, 2005, and 2007). The problems that Japanese firms have been experiencing in China were verified through interviewing the head of the procurement department. Regarding the problems in procurement, Table 3 summarizes the data information collected from the surveys. The surveys show that the problems with quality, cost, and delayed delivery in procurement remain a critical challenge. However, through research in this case study it has been identified that these three issues are directly affected by logistics problems. Therefore, by improving the level of logistics management in China the problems regarding these issues will greatly decrease.

Table2 Top three factors regarding difficulties and obstacles in procurement from China

\begin{tabular}{|c|c|c|c|}
\hline & Factor No. 1 & Factor No. 2 & Factor No. 3 \\
\hline Sourcing & $\begin{array}{c}\text { Quality } \\
\cdot \text { maintain quality level }\end{array}$ & $\begin{array}{c}\text { Cost } \\
\text { - price increase }\end{array}$ & $\begin{array}{l}\text { Delayed delivery } \\
\text { - unstable delivery }\end{array}$ \\
\hline $\begin{array}{l}\text { Supplier } \\
\text { selection }\end{array}$ & $\begin{array}{c}\text { Quality } \\
\cdot \text { maintain quality level }\end{array}$ & $\begin{array}{c}\text { Cost } \\
\text { - cost performance } \\
\end{array}$ & $\begin{array}{l}\text { Delayed delivery } \\
\text { - unstable delivery }\end{array}$ \\
\hline $\begin{array}{c}\text { Manufacturing } \\
\text { process }\end{array}$ & $\begin{array}{l}\quad \text { Quality } \\
\text { - inadequacies in } \\
\text { quality inspection } \\
\text { system }\end{array}$ & $\begin{array}{c}\text { Quality } \\
\text { poor equipment } \\
\text { maintenance }\end{array}$ & $\begin{array}{c}\text { Quality } \\
\text { - defective condition of } \\
\text { manufacturing facilities }\end{array}$ \\
\hline Logistics & $\begin{array}{l}\quad \text { Quality } \\
\text { - lack of container } \\
\text { trucks } \\
\text { - products damage } \\
\text { caused by poor } \\
\text { condition of } \\
\text { containers }\end{array}$ & $\begin{array}{l}\text { Quality / Cost } \\
\text { - rough treatment of } \\
\text { products } \\
\text { - instability of ocean } \\
\text { freight } \\
\text { - rising labor costs }\end{array}$ & $\begin{array}{l}\text { Quality / Delayed delivery } \\
\text { - different standard and } \\
\text { understanding of logistics } \\
\text { practice between China and } \\
\text { Japan } \\
\text { - delayed delivery due to } \\
\text { shortage of labor }\end{array}$ \\
\hline $\begin{array}{c}\text { Regulations } \\
\text { on distribution } \\
\text { and logistics }\end{array}$ & $\begin{array}{l}\text { Cost } \\
\text { - transshipment } \\
\text { caused by } \\
\text { restrictions }\end{array}$ & \begin{tabular}{l}
\multicolumn{1}{c}{ Cost } \\
- unclear customs \\
tariff (differing \\
from revenue \\
officer)
\end{tabular} & $\begin{array}{l}\text { Delayed delivery } \\
\text { - traffic regulations, especially } \\
\text { in major cities }\end{array}$ \\
\hline
\end{tabular}

Author summarized from interviewing the managers of the procurement department in the company.

\section{Some new issues: a rise in logistics costs, local labor costs, and a shortage of human resources are becoming major concerns.}

In addition, the findings revealed some new issues: a rise in logistics costs, local labor costs, and a shortage of human resources. Low costs and a rich supply of labor have to this point been the biggest advantages of expanding businesses in China; however, the changing environment, such as the rapid economic growth along with rising incomes, is now putting pressure on foreign firms and becoming a major concern for them. The interviewee pointed out that although delayed deliveries were mostly 
caused by logistics barriers in the past, presently this problem can be attributed to the shortage of manpower.

Table 3 Problems of procurement that face Japanese firms in the Chinese market

\begin{tabular}{|c|ccc|}
\hline & \multicolumn{4}{|c|}{$\begin{array}{c}\text { The rate of the respondents having problems of procurement } \\
(2003)\end{array}$} & $(2005)$ & $(2007)$ & (year) \\
\hline Quality & $84.8 \%$ & $72.9 \%$ & $76.5 \%$ \\
\hline Cost & $59.8 \%$ & $81.6 \%$ & $87.2 \%$ \\
\hline Delayed delivery & $64.3 \%$ & $49.2 \%$ & $64.4 \%$ \\
\hline
\end{tabular}

Source: The data were collected from the surveys of JCIPO (2003, 2005, and 2007).

\section{Conclusions}

Foreign firms in different industries are establishing effective strategies in their operations in China due to the growing importance of China's economy. The continuous success of those firms in the Chinese market may depend on how well they deal with the problems encountered there. Logistics issues greatly affect the business operation and performance in a huge developing market such as China. Through research in this case study it has been identified that logistics strategy is the key for procuring products at a low price from China. Quality, cost and delayed delivery are very common issues for foreign firms procuring from China. The present study has identified that they are seriously affected by logistics problems. Also, the logistics flow within China is where most problems regarding logistics arise in the entire business operation. The findings show that the logistics infrastructure has been improved; however, regulatory restrictions and local protection regulations still remain critical problems. The study also reveals that a rise in logistics costs, local labor costs, and a shortage of human resources are becoming new concerns in China.

It is important to recognize the challenges posed when entering the Chinese market and to anticipate how those issues can be improved and shaped in the future. As identified in this study, the logistics barriers attributed to hardware such as infrastructure have been improved; a reduction of other prominent barriers derived from various restrictions is essential for many foreign firms to practice standard logistics management in China. Furthermore, in order to achieve effective logistics management in China, a well-trained local work force cannot be underestimated. Additionally, though maintaining lower costs is important, it is an immediate task for foreign firms to cultivate human resources and secure experienced workers, along with developing their necessary skills and expertise. Investing in the local work force will be an important choice for foreign firms in the long term.

\section{References}

[1] A. Fredriksson, P. Jonsson, Assessing consequences of low-cost sourcing in China, International Journal of Physical Distribution \& Logistics Management, Vol. 39, No. 3 (2009) 227-249.

[2] A. Gunasekaran, E.W.T. Ngai, 3PL: experience from China resources logistics (Hong Kong), Logistics System and Management, Vol.1, No. 1 (2004) 81-97.

[3] H. Ta, H. Choo , and C. Sum, Transportation concerns of foreign firms in China, International Journal of Physical Distribution \& Logistics Management, Vol. 30 No. 1 (2000) 35-54.

[4] Japan's Balance of Payments, the Ministry of Finance (MOF), 2013.

[5] Japan-China Investment Promotion Organization (JCIPO) surveys, 2003, 2005, and 2007. 
[6] J. Bolton, and Y. Wei, Supply china management in China: Trends, risks, and recommendations, Accenture, Asset Vol. 6, June 2004.

[7] J. R. J. Carter, N. Pearson and L. Peng, Logistics berries to international operations: The case of the People's Republic of China, Journal of Business Logistics, Oak Brook, Vol.18 No. 2 (1997) 129-145.

[8] K. Hayashi, T. Nemoto, N. Hashimoto, and F. Kobayashi, Procurement logistics of auto parts in inland China-A case study of Japanese auto manufacturers in Sichuan, Journal of Japan Logistics Society, No.18 (2010) 201-208.

[9] K. H. Lau, and J. Zhang, Drivers and obstacles of outsourcing practices in China, International Journal of Physical Distribution \& Logistics Management, Vol. 36, No.10 (2006) 776-792.

[10] L. Yu, Major issues in supply chain management for international firms in China, Research on Logistics Review, No.46 (2006) 1-15.

[11] L. Zhang and K. Goffin, Joint Venture manufacturing in China: an exploratory investigation, International Journal of Operations \& Production Management, Vol. 19, No. 5/6 (1999) 474-490.

[12] L. Zhang and K. Goffin, Managing the transition-supplier management in international joint ventures in China, International Journal of Physical Distribution \& Logistics Management, Vol. 31 No. 2 (2001) 74-95.

[13] Robert Easton, On the Edge: The Changing face of supply chain management in China, Supply Chain Perspectives, Accenture, 2003.

[14] Y. A. Bolumole, The supply chain role of third-party logistics providers, International Journal of Logistics Management, Vol. 12 No.2 (2001) 87-102. 